\title{
Serum Concentration of , Zinc Copper, Manganese and Iron in Rheumatoid Arthritis Patients
}

\author{
Mayadah H.AL-Jammas \\ Department of Pharmacy \\ College of Pharmacy \\ Mosul University
}

\author{
Saad M. Alhasani \\ Rheumatology Section \\ College of Medicine \\ Ibin Sina Teaching Hospital
}

\author{
Mowafak K. Hassan \\ Department of Biology \\ College of Science \\ Mosul University
}

(Received 1/11 / 2009 ; Accepted 5/4 /2010)

\begin{abstract}
Rheumatoid arthritis, is a chronic multi-system disease, causes many systemic manifestation, the most characteristic of which is the symmetrical involvement of peripheral articulation by inflammatory synovitis. There is also a consideration that cellular immunity has some role in the genesis of the disease. Indeed RA has been described as T-lymphocyte -macrophage immunoregulation disorder. In this study, we evaluate the changes in serum levels of zinc $(\mathrm{Zn})$, copper $(\mathrm{Cu})$, iron $(\mathrm{Fe})$, manganese $(\mathrm{Mn})$ and the role of these elements in the pathogenesis of the disease.

22 patients with rheumatoid arthritis were evaluated clinically and biologically at Ibin Sina hospital in Mosul thirteen patients with active rheumatoid arthritis and 9 patients with inactive rheumatoid arthritis compared with 20 normal healthy subjects.

In the present study we observed significantly higher serum $\mathrm{Cu}$ levels in patients with RA compared with those in normal control subjects $(\mathrm{p}<0.0001)$. $\mathrm{Cu}$ in active patients were somewhat higher compared with non active RA patients.

On the contrary the results for serum zinc, manganese and iron levels in patients with active RA had significantly lower than that of normal control subjects $(\mathrm{p}<0.0001)$.A non significant difference also occur between active and inactive RA patients.

Rheumatoid arthritis induced significant changes in the level of copper, manganese and iron in rheumatoid arthritis patients but no significant changes between active and inactive patients .We therefore conclude that further studies are needed to see the effect of serum level of these minerals on the activity of RA and Researches in this side could open a new field in the management of RA at least as a complementary therapy with disease modifying anti- rheumatic drugs and biological agents, and interestingly these are dietary without side effects and inexpensive agents.
\end{abstract}

Keywords: Rheumatoid arthritis, ions, immunity, serum. 


\section{تركيز الخارصبن و النحس و المنغنيز و الحسدف أمصل المرض المصلبن

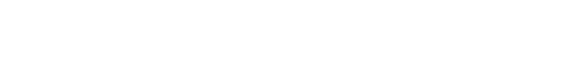

\section{المالخص}

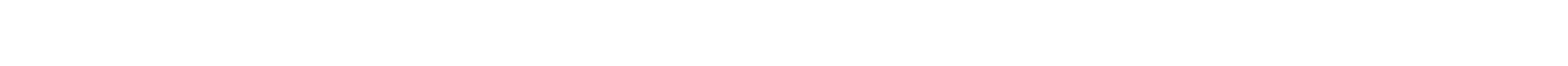
التهلب الغشاء المفصلي للمفاطل المحيطية ويكون متنظارا، هناك اعقاد أن للمناعة الخلوية دور في إحداث

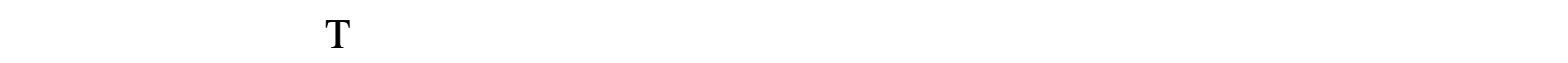
الدرلسة قيلس التغيرات في مستوى كل من الزكك، النحلس، المنغنيز والحديد في المصل ودور هذه العناصر

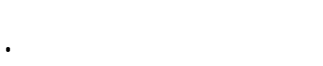
شملت الدرلسة 22 مريضا مصل بالتهلب المفاصل الرثوي (13 في الطور الفعل و9 في الطور غير فعل ) مقارنة 20شخصا من الأصحاء. لظٔهرت نتائج الدرلسة الحالية زيادة معنوية في مستوى النحلس في المصل للمرضى مقارنة بالأصحاء،

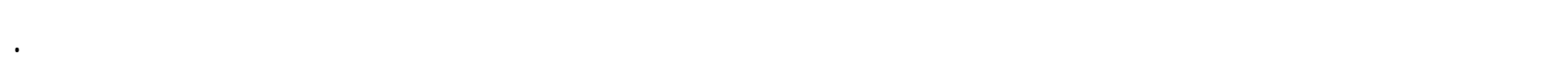

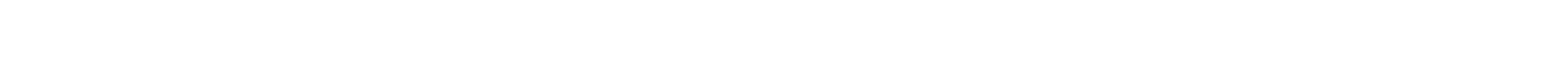

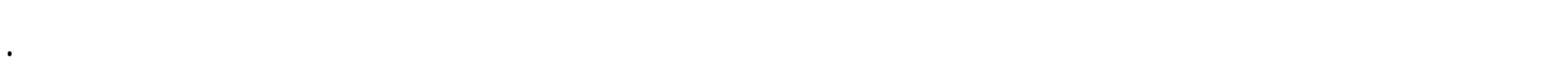

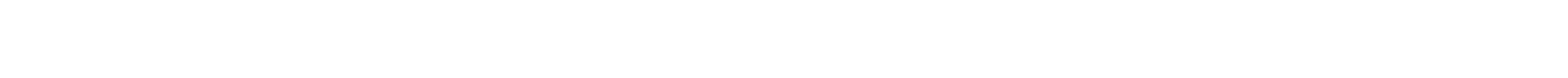

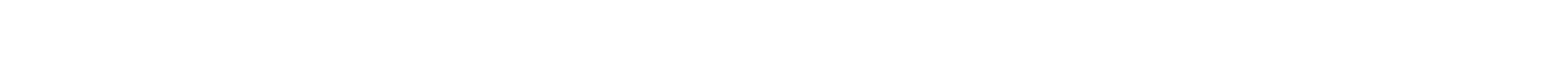

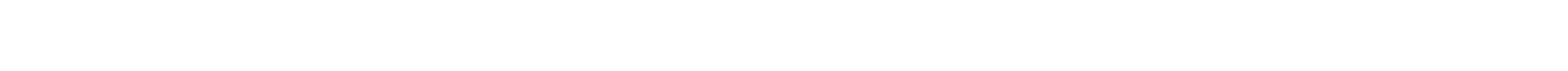
جانبية كما أنها غير مكلفة ماديا. الكاملت الدالة: التهلب المفاصل الرثوي، ايونات، مناعة، مصل. 